\title{
Market Orientation towards Students and Organizational Performance: Perceptions of Accounting Department Chairpersons of Public and Private Business Schools Belonging to AACSB
}

\author{
Robert L. Webster \\ Ouachita Baptist University \\ 410 Ouachita St, Arkadelphia, AR 71998, USA \\ Jeanie A. Curry \\ Ouachita Baptist University \\ 410 Ouachita St, Arkadelphia, AR 71998, USA \\ Kevin L. Hammond \\ University of Tennessee at Martin \\ College of Business and Public Affairs \\ 554 University St, Martin, TN 38237, USA
}

\begin{abstract}
This manuscript reports results of a national survey of Accounting Department Chairpersons examining levels of reported market orientation toward students and explores its impact on business school performance for both private and public business schools. Specifically the research seeks to determine if private business schools and public business schools exhibit differing levels of market orientation toward students and if so, do differing levels affect perceived organizational performance. The business schools studied were all members of AACSB. AACSB member schools were chosen to study as they all have gone through rigorous examination from an outside agency and have demonstrated their high performance standards. 98 accounting department chairs responded to the survey. Of the 98 respondents, 39 were from private schools and 59 were from public schools. The manuscript details the data collection and analysis processes, the statistical findings, implications for business schools, and presents a call for additional research.
\end{abstract}

Keywords: Market Orientation, Business School Performance, AACSB Schools

\section{Introduction}

All colleges and universities strive to attain and maintain high levels of performance. Numerous organizational strategies have been used in the pursuit of superior performance. Examples of such strategies in higher education include a service strategy, a research centered strategy, a student centric strategy or a market orientation strategy. This research investigates if organizational performance of business schools belonging to AACSB may be positively influenced by the use of a market orientation strategy toward students. AACSB member schools were chosen as their high standards were attested to via the accreditation process and therefore all had a certain commonality. Market orientation is described as an organizational culture in which everyone in the organization is committed to the customer and adapts in a timely manner to meeting the changing needs of the customer. Market orientation blends an organizational culture dedicated to providing superior value with successfully achieving a customer focus, acquiring competitor intelligence, and maintaining interfunctional coordination. It is viewed as the implementation of the marketing concept. AACSB standards for business school accreditation outline requirements that if met lead to accreditation thereby elevating the status of the school as well as indicating superior performance. Additionally, the Baldrige National Quality Program (BNQP 2005) has established the Baldrige Education Criteria for Performance Excellence for universities and other educational organizations, and includes a "student, stakeholder, and market focus category" (BNQP 2005) among the criteria leading to performance excellence. This particular category of criteria suggests that organizations identify potential market segments and determine which ones to pursue, then take steps to learn "key requirements and changing expectations," build relationships, increase loyalty, and determine satisfaction/dissatisfaction of those student/stakeholder markets. 
The focus category also emphasizes the importance of strategic decisions regarding the extent that university business schools may choose to focus on particular markets, and the balance of focus between chosen markets. These decisions may obviously contribute to the culture of the school, encouraging or discouraging attentiveness to students and potential students, parents of students, future employers of graduates, and other student/stakeholder markets. Market selection and other applications of marketing theory by practitioners within higher education are appropriate and should certainly be beneficial. The idea that organizations of higher education should employ marketing strategies to improve their performance appeared in the literature as early as the 1960s. Kotler and Levy (1969) were pioneers in successfully arguing for broadening the scope of marketing (and the marketing concept) to include higher education as well as other nonbusiness organizations. In the marketing literature, the establishment and use of a market orientation strategy has been shown to increase levels of performance in businesses. This paper investigates the level of market orientation toward students within AACSB schools of business located in the United States and its impact, if any, on perceived organizational performance. More specifically the paper investigates if differences exist between private and public business schools in the implementation of a market orientation strategy and if so, do the differences impact organizational performance.

\section{Discussion and Literature Review}

Excellence of performance in higher education is self-evidently important. In accounting and in the other business disciplines, excellence is assessed and assured by the qualification standards of the bodies awarding formal accreditation to business schools (Karathanos and Karathanos 1996). For American business schools, the main accreditation body is AACSB (the Association to Advance Collegiate Schools of Business). Performance is ranked more informally in the U.S. by the annual guides published by U.S. News and World Report and by the Peterson's web-based educational information resource, both directed at prospective students, their parents and their advisers. The BNQP (2005), mentioned above, incorporates behaviors and actions indicative of high levels of market orientation throughout its education criteria for performance excellence as described in the marketing literature, [see (Kohli and Jaworski 1990; Narver and Slater 1990; Jaworski and Kohli 1993; Slater and Narver 1994; Hammond, Webster, and Harmon 2006; Webster, Hammond, and Rothwell 2010; Hemsley-Brown and Oplatka, 2010; and Zakaria, Roslin and Daud, 2011)]. Further, the marketing literature (Barksdale and Darden 1971; Houston 1986; Kohli and Jaworski 1990; Narver and Slater 1990; Jaworski and Kohli 1993; Siguaw, Brown, and Widing 1994) supports assertions by practitioner-oriented publications such as the BNQP 2005 that these behaviors and actions result in a greater ability of the organization to achieve its objectives and attain higher levels of performance.

The term "market orientation" refers to the extent that an organization employs the marketing concept. Kohli and Jaworski describe the processes required to engender a market orientation as a "distinct form of sustainable competitive advantage" (1990). They state that market orientation consists of "the organizationwide generation, dissemination, and responsiveness to market intelligence" (1990). Narver and Slater agreed with Kohli and Jaworski, proposing three behavioral components (customer orientation, competitor orientation, interfunctional coordination) that "comprehend the activities of marketing information acquisition and dissemination and the coordinated creation of customer value" (1990).

Although the idea of adopting a market orientation strategy as a means of improving organizational performance in higher education dates back to the 1960s, only recently have studies of market orientation in higher education been found in the literature. Hammond, Webster, and Harmon (2006) provided a comparison of the market orientation components to criteria for performance excellence described in the BNQP 2005. They also demonstrated a link between levels of market orientation and organizational performance, the first such study to do so in a higher education context. Oplatka and Hemsley-Brown (2007) analyzed the implications of market orientation for managers in a school environment and suggested an approach to incorporating market orientation into the school culture, with an emphasis on leadership's key role in that process. They concluded that customer orientation, with a focus on students, was a key component in helping administrators, managers and teachers to understand the school and its environment, and be capable of creating and providing value over time. Lewison and Hawes (2007) suggested that students are an important target market for a university and should be viewed as customers. They explored the relative merits of mass marketing and target marketing and concluded that the "intangible and perishable nature" of the higher education product increases the need for identifying a target market and developing a strategy to reach it. 
Hammond, Webster, and Harmon (2009) questioned if schools of different sizes and faculty make-up have a different approach to market orientation toward students. Ma and Todorovic (2011) surveyed department chairs of computer science, engineering, and health science departments in universities across the U.S. Their results showed that market orientation does contribute significantly to university department performance, but they concluded that the external community, rather than the student, is the appropriate university customer. Hammond and Webster (2014) investigated gender differences concerning perceptions of market orientation and performance within higher education. Webster, Hammond, and Rothwell (2017) researched similarities and differences in market orientation perceptions between differing levels of management within business schools.

Webster and Hammond (2018) investigated the market orientation and performance relationship using multiple customer groups and multiple organizational levels within higher education. Although not in the realm of higher education, in one of the first studies to examine the relationship between market orientation and performance over time, Kumar, Jones, Venkatesan, \& Leone (2011) showed that market orientation has a positive influence in both the short and the long run. They concluded that since the benefits of market orientation take time to become fully realized, the importance of management in supporting a market-oriented culture is vital. Their findings may well be appropriate to the world of higher education. This study is an extension of previous research cited above. In this paper we investigate the impact of market orientation on perceived business school performance as reported by accounting department chairpersons of AACSB member schools. Then, we separate the respondents into two groups, private schools and public schools and research the following questions.

\section{Research Questions}

The objectives of this study are to answer the following research questions:

1.Can existing scales be reworded and used to produce reliable and valid measurements of market orientation and overall performance in the context of the university setting?

2. What are the mean scores of the market orientation scale and the organizational performance scale reported by the accounting department chairpersons (by all chairs, private school chairs and public school chairs)? Are mean scores different for private school and public school accounting chairs for the market orientation and organization performance variables?

3.Do levels of reported market orientation toward students impact the level of reported organizational performance within business schools belonging to AACSB?

4.Do levels of reported market orientation toward students impact the levels of reported organizational performance differently for private schools than public schools of business belonging to AACSB?

To address Research Question 1, we reworded Narver and Slater's (1990) market orientation scale. Narver and Slater explain that this scale, consisting of three behavioral components, is also consistent with the findings of Kohli and Jaworski (1990). The behavioral components of the scale include the activities described by Kohli and Jaworski (1990). The two sets of authors agreed that market orientation is continuous rather than dichotomous and, addressing concerns raised by Barksdale and Darden (1971), is properly measured in terms of behaviors and activities instead of "philosophical notions." Accordingly, the Narver and Slater measure consists of several questions addressing specific behaviors and activities that, together, measure the extent that the organization (or organizational unit) applies the marketing concept. The market orientation scale of Narver and Slater is reworded as necessary and applied to the students. The survey is discussed more fully in the Methodology section of the paper.

"Overall performance" is measured using a slightly modified Jaworski and Kohli (1993) two-item measure that is based on respondent opinion of performance. This subjective measure incorporates differences in performance goals that exist from school to school by simply requesting the accounting department chairs indicate the recent overall performance of the school of business, from poor to excellent. The wide range of possible performance goals, then, is not assumed in the survey but is left for the respondent to decide which goals should influence their responses. Each respondent should answer the questions about actual overall performance relative to the expectations and performance goals of their school. Slater and Narver (1994) echo Jaworski and Kohli's defense of the use of subjective performance measures, noting that the measures "are used commonly in research on private companies or business units of large corporations." Slater and Narver (1994) also noted the "strong correlation between subjective assessments and their objective counterparts" found in previous business research. 
Research question 1 is addressed through psychometric analysis of the scales. The scales and their development are more fully discussed in the Methodology section of this paper and the psychometric analysis is addressed in the Results section.

To answer question 2, the mean scores for the market orientation dimensions are computed for the private schools and public schools and the same is accomplished for the overall performance variable. Comparisons of the variables are then made by way of a series of t-tests for significant statistical differences.

To address question 3, regression models are constructed and analysis of variance of the regression models is undertaken to determine if the independent variables, those being the three constructs of market orientation (customer orientation, competitor orientation, and interfunctional coordination), have a significant statistical effect on the dependent variable, organizational performance.

To address question 4, regression models are constructed and analysis of variance of the regression models is undertaken to determine if the independent variables, those being the three constructs of market orientation (customer orientation, competitor orientation, and interfunctional coordination), have a significant statistical effect on the dependent variable, organizational performance for both private business schools and public business schools belonging to AACSB.

\section{Methodology}

Data for the study were collected by way of a mailed survey. Survey instruments along with a cover letter were mailed to accounting department chairpersons of schools of business located in the United States holding membership in AACSB. The accounting chairs were asked to complete the surveys and return them in business reply envelopes that were provided. Of the total survey instruments mailed, 98 were completed and returned. Of the 98 responses received, 59 were from public school accounting chairs and 39 were from private school accounting chairs. The overall response rate was approximately $20 \%$.

To measure market orientation, we chose Narver and Slater's (1990) construct (MKTOR), which consists of several questions addressing specific behaviors and activities which, together, measure the extent that the organization (the university accounting department, in this case) applies the marketing concept. The scale addresses concerns raised by Barksdale and Darden (1971) that market orientation is properly measured in terms of behaviors and activities instead of "philosophical notions." A seven point response scale is used ranging from one (1) "not at all" to seven (7) "to an extreme extent." Scores above the midpoint (4.0) indicate application by the respondent of the marketing concept; scores below the midpoint indicate a lack of application by the respondent. Questions from the original scale were modified somewhat to conform to the vocabulary prevalent in academic institutions and, as noted above, to avoid referring to students as "markets" or "customers." We combine the questions to form three subscales that measure the market orientation components (customer orientation, competitor orientation, and interfunctional coordination), matching Narver and Slater's methodology. The subscales combine to form an overall measure of market orientation, also matching Narver and Slater's methodology. 15 questions were used in the collection of the customer and market orientation data. The questions and explanatory information about the survey questions may be found in appendix 1 at the end of the paper. "Overall performance" is measured using the modified subjective Jaworski and Kohli (1993) two-item measure that is based on executive opinion of performance. No specific performance goals are assumed for the respondents. Each respondent is requested to answer the two questions about actual recent overall performance relative to the expectations and performance goals of their organization, in this case the school of business. Possible responses on the seven point scale range from poor (1) to excellent (7). The survey questions may be found in appendix 2 at the end of the paper. Slater and Narver (1994) defend the use of subjective performance measures, noting that the measures "are used commonly in research on private companies or business units of large corporations" as well as the "strong correlation between subjective assessments and their objective counterparts" indicated in previous research.

The possibility of nonresponse bias was investigated by comparing early and late respondents (Armstrong and Overton 1977). The tests indicated no significant differences between early and late respondents (at the .10 level of significance). Also, Berdie (1989) found that, even in the event of nonresponse bias in mail surveys, typically the bias did not alter the survey findings. We proceeded on the basis that significant nonresponse bias did not exist. 


\section{Results}

After receiving the surveys back from the respondents, the reworded Narver and Slater scale was subjected to reliability analysis, exploratory factor analysis and confirmatory factor analysis (Wheaton, Muthen, Alwin, \& Summers 1997; Bentler \& Bonett 1980; Marsh \& Hocevar 1985; Bentler 1990; Browne \& Mels 1992; and Browne \& Cudeck 1993). Results of these analyses indicated satisfactory reliabilities (ranges from .73 to .91), satisfactory item-to-total correlations (ranges from 0.4 to 0.8 ), exploratory factor loadings ranging from 0.5 to 0.8 , and confirmatory factor loading ranging from 0.4 to 0.8 . Additionally, the confirmatory factor analysis demonstrated generally acceptable fit. These test results included comparative fit index measures ranging from .784 to 1.000 , a Tucker-Lewis index ranging from .702 to 1.000 , and the CMIN/DF ranging from 2.05 to 2.56. The RMSEA low values at the $90 \%$ confidence interval fell below 0.10 for all scales. The Pearson correlation coefficient for the two-item overall performance scale was computed to be .709 (sign. .000), indicating reliability for this two-item scale. These results indicate that research question 1 may be answered in the affirmative.

\section{Table 1 Descriptive Statistics}

Mean Scores For Market Orientation Constructs (3), Overall Market Orientation, And Performance Indicator For AACSB 1.Accounting Chairs Total / 2.Private School/ 3. Public School

\section{Point Scales}

\begin{tabular}{lrll}
\multicolumn{1}{r}{ Description } & \multicolumn{1}{c}{ Mean } & Std. Dev. & N \\
& & & \\
MO-Customer & $4.44 / 4.77 / 4.22$ & $.979 / .962 / .955$ & $98 / 39 / 59$ \\
MO-Competition & $3.40 / 3.81 / 3.12$ & $1.28 / 1.42 / 1.17$ & $98 / 39 / 59$ \\
MO-Coordination & $3.71 / 4.13 / 3.44$ & $1.16 / 1.16 / 1.09$ & $98 / 39 / 59$ \\
MO-Overall & $3.85 / 4.24 / 3.60$ & $1.17 / 1.10 / .925$ & $98 / 39 / 59$ \\
PERFORMANCE & $5.27 / 5.47 / 5.14$ & $1.00 / 1.09 / .937$ & $98 / 39 / 59$
\end{tabular}

After reporting the descriptive statistics for the three groups shown in Table 1 above, t-tests were performed to test for differences in mean scores between the private school and public school accounting department chairs. The results showed that the differences in mean scores between the private and public chairpersons were statistically significant at the 0.01 level for each of the four Market Orientation measures. As can be seen in Table 1 , the mean scores in each of the reported categories are higher for the private school chairs than the public school accounting chairs. The mean score for private school chairs was also higher than for the public school chairs for the performance variable. The t-test for the performance variable found there was a statistically significant difference between the mean scores of the public and private school respondents but only at the 0.10 level. Table 1 and the set of t-tests answer research question 2. These findings would seem indicate that as market orientation scores become higher, so also do the performance indicator scores, at least as far as the accounting chairs in this study are concerned. To further investigate this premise, a set of regression models were developed and analyzed. These regression equations are described and explained below. Following the descriptions of the regression models will be a discussion of the results of the various models.

The regression models developed to answer research questions 3 and 4 were: $Y=b_{0}+b_{1} x_{1}+b_{2} x_{2}+b_{3} x_{3}$ where: $\mathrm{Y}=$ mean score of the two-item performance scale as reported by (1) accounting chairs in total,(2) public school accounting chairs, (3) private school accounting chairs $\mathrm{b}_{0}=$ intercept

$\mathrm{x}_{1}=$ mean score of the customer orientation construct as reported by the accounting department chairs by group 1,2,3

$\mathrm{x}_{2}=$ mean score of the competitor orientation construct as reported by the accounting department chairs by group $1,2,3$

$\mathrm{x}_{3}=$ mean score of the interfunctional coordination construct as reported by the accounting department chairs by group $1,2,3$. 
Tables 2, 3, and 4 that follow present the results of the regression equations. As can be seen below, the F-tests for all three of the regression models are statistically significant in that all show that organizational performance is positively affected by market orientation scores. These models and the analysis that follow provide insight and answers to research questions 3 and 4.

\section{Table 2 F-Test Scores For The Multiple Regression Model}

Market Orientation Component Scores Effect on Performance As Reported By AACSB Accounting Department Chairs

\begin{tabular}{|c|c|c|}
\hline \multicolumn{3}{|c|}{$\mathrm{N}=98$} \\
\hline Source & $\mathrm{F}$ & Significance \\
\hline Model & 13.592 & .000 \\
\hline MO/Customer & 4.184 & .044 \\
\hline MO/Competition & 8.685 & .004 \\
\hline MO/Coordination & 0.141 & .708 \\
\hline
\end{tabular}

*R Squared=.296 (Adjusted R Squared=.274)

Table 3 F-Test Scores For The Multiple Regression Model

Market Orientation Component Scores Effect on Performance Private School AACSB Accounting Department Chairs

$\begin{array}{lccc} & \mathrm{N}=39 & & \\ \text { Source } & \mathrm{F} & \text { Significance } \\ \text { Model } & 7.99 & .000 \\ \text { MO/Customer } & 4.07 & .050 \\ \text { MO/Competition } & 5.09 & .030 \\ \text { MO/Coordination } & 0.39 & .537\end{array}$

*R Squared=.407 (Adjusted R Squared=.356)

Table 4 F-Test Scores For The Multiple Regression Model

Market Orientation Component Scores Effect on Performance Public School AACSB Accounting Department Chairs

*R Squared=.193 (Adjusted R Squared=.149)

\begin{tabular}{|c|c|c|}
\hline \multicolumn{3}{|c|}{$\mathrm{N}=59$} \\
\hline Source & $\mathrm{F}$ & Significance \\
\hline Model & 4.39 & .008 \\
\hline MO/Customer & 0.50 & .483 \\
\hline MO/Competition & 3.36 & .072 \\
\hline MO/Coordination & 0.04 & .845 \\
\hline
\end{tabular}

\section{Implications}

This research finds that a market orientation strategy (or culture) as defined in the marketing literature does indeed affect and have some explanatory power as far as organizational performance is concerned, at least as reported by the accounting department chairs. Although the statistical difference in the organizational performance variable was found to be at only the 0.10 of level significance between the private school and public accounting chairs, this independent variable seemed to be influenced and explained by higher levels of the market orientation. This research found, as has previous research conducted on business organizations and within some educational organizations, that performance may be improved by increasing levels of market orientation. As students of the university may be viewed as the most visible of the numerous markets served, market orientation efforts focused at students would seem to have the potential for the fastest and highest payoff. Examples of such payoffs, all of which might correctly be viewed as performance indicators might include:

1.An increase in enrollment within the business school and accounting department

2. An increase in the number of business/accounting majors

3. An increase in the retention rate of current business/accounting students

4. An increase in the number and percentage of business and accounting graduates 
In view of Narver and Slater (1990) and Kohli and Jaworski (1993) findings that enhanced levels of market orientation will improve the competitive advantage of organizations, business schools appear to be organizations ripe to take advantage of the market orientation concept. Focus on creating a market orientation culture should serve both schools and their various stakeholders, not just students, in more effectively achieving accounting department and business school objectives. Our conclusions are tempered by the findings of Noble, Sinha, \& Kumar (2002) and Haugland, Myrtveit, \& Nygaard (2007) that there appears to be no single strategic orientation that leads to superior performance in every case; and building a market orientation culture within an organization is not a quick fix but rather a continuous process.

\section{Future Research}

The research we report leaves open several related areas of interest for additional study. Examples include research to determine the impact or influence that variables such as size of a school, school affiliation (AACSB, ACBSP, or neither), admission standards, placement efforts, or recruiting efforts have on customer and market orientation. Also, research on other stakeholders such as parents of students, employers of students, and alumni associated with schools of business would be useful. Such research would further our understanding of the market orientation construct and its application to higher education.

\section{References}

Armstrong, J. S. \& Overton, T. S. (1977) Estimating nonresponse bias in mail surveys. Journal of Marketing Research, 14 (August), 396-402.

Barksdale, H. C. \& Darden, B. (1971) Marketers attitude toward the marketing concept. Journal of Marketing, 35 (October), 29-36.

Bentler, P. M. (1990) Comparative fit indexes in structural models. Psychological Bulletin, 107, 238-246.

Bentler, P. M. \& Bonett, D. G. (1980) Significance tests and goodness of fit in the analysis of covariance structures. Psychological Bulletin, 88, 588-606.

Berdie, D. (1989) Reassessing the value of high response rates to mail surveys. Marketing Research, 1, 52-64.

BNQP (2005), "Baldrige Education Criteria for Performance Excellence," Baldrige National Quality Program, www.quality.nist.gov/Education_Criteria.htm.

Browne, M. W. \& Cudeck, R. (1993) Alternate ways of assessing model fit. In Bollen, K. A. \& Long, K. S. (Eds.) Testing structural equation models. Newbury Park, California: Sage, 136-162.

Browne, M. W. \& Mels, G. (1992) RAMONA User's Guide. The Ohio State University, Columbus, Ohio.

Dwyer, F. R., \& Welsh, M. A., (1985) Environmental relationships of the internal political economy of marketing channels. Journal of Marketing Research, 22, (November), 397-414.

Felton, A. P. (1959) Making the marketing concept work. Harvard Business Review, 37, (July-August), 55-65.

Hammond, K L., Webster, R. L., \& Harmon, H. A., (2006) Market orientation, top management emphasis, and performance within university schools of business: implications for universities. Journal of Marketing Theory and Practice, (Winter), Vol. 14, No. 1, 69-85.

Hammond, K L., Webster, R. L., \& Harmon, H. A., (2009) The impact of market orientation toward students and student/faculty ratios on performance excellence in the case of AACSB-international member schools. Academy of Marketing Studies Journal Vol 13 No. 2, 187-194.

Hammond, K L., Webster, R. L., (2014) Marketing department chairs as key informants-the role of gender in judging the consequences of student market orientation within AACSB member schools. Academy of Educational Leadership Journal Vol 18 No. 4, 187-194.

Haugland, S.A., Myrtveit, I., \& Nygaard, A. (2007) Market orientation and performance in the service industry: A data envelopment analysis. Journal of Business Research Vol. 60 No. 11, (Nov). 1191-1197.

Hemsley-Brown, J. \& Oplatka, I. (2010) Market orientation in universities: a comparative study of two national higher education systems. International Journal of Educational Management Vol 24 No. 3, 201-220.

Houston, F. S. (1986) The marketing concept: what it is and what it is not. Journal of Marketing, 50 (April), 8187.

Hunt, S. (1990) Commentary on an empirical investigation of a general theory of marketing ethics. Journal of the Academy of Marketing Science, 18, (Spring), 173-177.

Jaworski, B. J. \& Kohli, A. K. (1993) Market orientation: antecedents and consequences. Journal of Marketing, 57 (July), 53-70. 
Karathanos, D. \& Karathanos, P. (1996) The Baldridge education pilot criteria 1995: An integrated approach to continuous improvement in education. Journal of Education for Business, 71 (May/June), 272-276.

Kohli, A. K. \& Jaworski, B. J. (1993) Market orientation: the construct, research proposition, and managerial implications. Journal of Marketing, 54 (April), 1-18.

Kotler, P. (1980) Marketing Management: Analysis. Planning and Control, (4th ed.) Englewood Cliffs, NJ: Prentice-Hall, Inc.

Kumar, V., Jones, E., Venkatesan, R. \& Leone, R. (2011) Is market orientation a source of sustainable competitive advantage or simply the cost of competing? Journal of Marketing, 75 (January), 1-31.

Larson, R. \& Catton, W., Jr. (1959) Can the mail-back bias contribute to a study's validity? American Sociological Review, XXIV, 243-245.

Levitt, T. (1969) The Marketing Mode. New York: McGraw-Hill Book Company.

Lewison, D. \& Hawes, J. (2007) Student target marketing strategies for universities. Journal of College Admission (Summer), 14-19.

Ma, J. \& Todorovic, Z. (2011) Making universities relevant: market orientation as a dynamic capability within institutions of higher learning. Academy of Marketing Studies Journal, 15(2), 1-15.

Marsh, H. W. \& Hocevar, D. (1985) Applications of confirmatory factor analysis to the study of self-concept: first -and higher-order factor models and their invariance across groups. Psychological Bulletin, 97, 562-582.

McNamara, C. P. (1972) The present status of the marketing concept. Journal of Marketing, 36 (January), 50-57.

Morse, R. J. \& Flanigan, S. M. (2000) America's best colleges-how we rank them. U.S. News and World Report, (September 11), 104-105.

Narver, J. C., Park, S. Y. \& Slater, S. F. (1992) Market orientation, information, and marketing strategies. American Marketing Association Summer Educators Conference.

Narver, J. C. \& Slater, S. F. (1990) The effect of a market orientation on business profitability. Journal of Marketing, 54 (October), 20-35.

Noble, C. H., Sinha, R. J., \& Kumar, A. (2002) Market orientation and alternative strategic orientations: a longitudinal assessment of performance implications. Journal of Marketing, 66 (October), 25-39.

Oplatka, I. \& Hemsley-Brown, J. (2007), The incorporation of market orientation in the school culture: an essential aspect of school marketing. International Journal of Educational Management, Vol. 21 No. 4, 292-305.

Peterson's Guide to Four Year Colleges, 2001, 31st ed. (2000) Lawrenceville, NJ: Peterson's/Thomson Learning.

Siguaw, J. A., Brown, G. \& Widing, R. E., II, (1994) The influence of the market orientation of the firm on sales force behavior and attitudes. Journal of Marketing Research, 31 (February), 106-116.

Slater, S. F. \& Narver, J. C. (1994) Does competitive environment moderate the market orientation-performance relationship? Journal of Marketing, 58 (January), 46-55.

Webster, R.L., Hammond, K.L., \& Rothwell, J.C. (2010) Customer and market orientation within AACSB member business schools: comparative views from three levels of administrators. American Journal of Business Education, Vol. 3, No. 7, 79-91.

Webster, R.L., Hammond, K.L., \& Rothwell, J.C. (2017) Effects of market orientation on business school performance: a view from marketing department chairpersons and business school deans of AACSB member schools. International Journal of Business and Social Science Vol 8 No. 3, 24-31.

Webster, R.L. and Hammond, K.L. (2018) Is business school performance impacted by market orientation toward students, employers of students, and parents of students? Views from accounting department chairpersons, business school deans, and academic vice-presidents of AACSB business schools. Journal of Modern Accounting and Auditing Vol 14 No.2. 49-59.

Wheaton, B., Muthen, B., Alwin, D. F., \& Summers, G. F. (1977) Assessing reliability and stability in panel models. In Heise, D. R. (Ed.) Sociological Methodology 1977. San Francisco: Jossey-Bass, 84-136.

Zakaria, Z., Roslin, R.M., \& Daud N.M. (2011) The influence of market orientation on the commitment, trust and relational norms in the education context. African Journal of Business Management Vol 5 (22), 88758890. 


\section{APPENDIX 1}

Market Orientation Survey Questions Sent to Accounting Department Chairs of AACSB Schools of Business

1. Our objectives are driven by satisfaction of our students.

2. We measure satisfaction of our students systematically and frequently.

3. Those responsible for recruiting students regularly share information within our business school/institution concerning competitor's strategies.

4. Our market strategies (such as recruiting and retention) are driven by our understanding of the possibilities for creating value for our students.

5. We respond rapidly to competitive actions that threaten us.

6. We constantly monitor our level of commitment and orientation to students.

7. University administration regularly discusses competitors' strengths and strategies.

8. All levels of administration understand how the entire institution can contribute to creating value for students.

9. We give close attention to service of students after enrollment.

10. Our strategy for competitive advantage is based on our understanding of our students needs.

11. We encourage other staff and faculty outside of recruiting/administration to meet with our prospective students.

12. All of our departments are responsive to and integrated in serving students.

13. Information on recruiting successes and failures are communicated across functions in the business school/institution.

14. We share information and coordinate resource use with other units in the institution.

15. We target potential students where we have, or can develop a competitive advantage.

Each question answered on a 7 point scale: 1=Not At All, 7=To an Extreme Extent. Questions 1, 2, 4, 6, 9, and 10 relate to the Customer Orientation construct/dimension, Questions 3, 5, 7, 11, and 15 relate to the Competitor Orientation, Questions 8,12,13, and 14 relate to Organizational Coordination. The Overall Marketing Orientation score is computed by averaging the mean scores of the other three sets of questions.

\section{APPENDIX 2}

Performance Measurement Questions Sent to Accounting Department Chairs of AACSB Schools of Business

1. Overall performance of the school of business last year was.

2. Overall performance of your school of business relative to major competitors last year was.

Both questions answered on a 7 point scale: 1=Poor, 7=Excellent 